\title{
ПРОБЛЕМИ КРИМІНАЛЬНОЇ ВІДПОВЦДАЛЬНОСТІ ЗА ДИФАМАЦІЮ В ПРОФЕСІЙНІЙ ДІЯЛЬНОСТІ ЖУРНАЛІСТІВ
}

\author{
ПАХНІН Микола Леонідович - кандидат наук 3 державного управління, \\ доцент кафедри кримінального права та кримінології факультету № 6 \\ Харківського національного університету внутрішніх справ \\ DOI 10.32782/NP.2021.4.12
}

Вивчається необхідність та доцільність впровадження в національне законодавство кримінально-правових норм про наклеп та образу (дибамаиію) та їх вплив на свободу слова та журналістську діяльність. Автором проведений порівняльно-правовий аналіз кримінальних законів зарубіжних країн щодо кримінальної відповідальності за вказані дї. Встановлено, що практично кожна країна Європи, а також значна кількість країн СНД мають норми про кримінальну відповідальність за дифамацію (у різних ï варіачіях). Досліджуються аргументи як противників, так і прихильників впровадження кримінально-правової заборони дифамачій. Робиться висновок про можливість впровадження відповідальності за наклеп та образу як суто превентивного заходу впливу на порушника у випадку умисного розповсюдження завідомо неправдивої інформаu̧ii.

Ключові слова: свобода слова, право на інформачію, дифамачія, наклеп, образа, кримінальна відповідальність.

Изучается необходимость и целесообразность внедрения в национальное законодательство уголовно-правовых норм о клевете и оскорблении (диффамации) и их влиянии на свободу слова и журналистскую деятельность. Автором проведен сравнительно-правовой анализ уголовных законов зарубежных стран в отношении уголовной ответственности за указанные действия. Установлено, что большинство стран
Европы, а также стран СНГ имеют нормы об уголовной ответственности за диффамацию (в разных вариациях). Исследуются аргументы как противников, так и сторонников введения уголовно-правового запрета диффамации. Делается вывод о возможности внедрения ответственности за клевету и оскорбление как исключительно превентивной меры воздействия на нарушителя в случае умышленного распространения заведомо ложной информации.

Ключевые слова: свобода слова, право на информацию, диффамация, клевета, оскорбление, уголовная ответственность.

\section{Вступ \\ У 2001 році 3 прийняттям нового} Кримінального кодексу України в нашій державі була декриміналізована відповідальність за наклеп та образу. Однак до цього часу питання необхідності встановлення кримінальної відповідальності за дифамацію залишаються дискусійним, а до Верховної Ради України неодноразово подавалися пропозиції з відновлення кримінальної відповідальності за вказані правопорушення.

Проблематикою кримінально-правового захисту діяльності засобів масової інформації займалися П. П. Андрушко, А. П. Бабій, П. С. Берзін, Я. С. Безпала, Р. В. Вереша, Ю. В. Городецький, I. О. Зінченко, В. М. Кудрявцев, С. Я. Аихова, Г. В. Аазутіна, А. І. Марущак, М. І. Мельник, О. В. Красильнікова, 


\section{Адміністративне право}

Н. В. Кушакова, В. I. Павликівський, А. В. Тарасенко, В. I. Тютюгін та ін.

\section{Мета дослідження}

3 урахуванням положень національного законодавства та досвіду зарубіжних країн дослідити проблему кримінальної відповідальності за дифамацію, а також ії вплив на свободу слова та діяльності журналістів.

Завданням дослідження $є$ проведення порівняльно-правового аналізу кримінальних законів європейських країн про дифамацію 3 урахуванням положень вітчизняного законодавства про відповідальність за наклеп та образу.

\section{Основний текст}

Одним 3 найвагоміших аргументів противників поновлення криміналізації за наклеп та образу - це можливість використання закону для обмеження свободи слова та журналістської діяльності. За висновками Європейського Суду з прав ^юдини, запровадження кримінальної відповідальності створює «охолоджувальний» вплив на журналіста та його професійну діяльність.

Так, у рішенні від 28.09.1999 р. у справі «Далбан проти Румунії» (Dalban v. Romania) - журналіста, засудженого у Румунії за наклеп на чиновника, який полягав в оприлюдненні інформації щодо неправомірних дій останнього, без належних на те доказів, Європейський Суд зазначив, що публікації журналіста стосувалися справи загального інтересу: управління державними активами і того, як політики виконують вимоги свого мандата [1, с. 44-46]. Суд визначив, що інтереси демократичного суспільства полягають у тому, щоб преса мала можливість надавати інформацію, яка становить значний громадський інтерес. Неприпустимо позбавляти журналіста можливості висловлювати критичні судження, якщо він не може довести їх правдивість. Суд вказав, що обвинувачення Далбана у вчиненні кримінального правопорушення та засудження його до позбавлення волі було непропорційним втручанням у його свободу вираження поглядів як журналіста, у зв'язку з цим порушують ст. 10 Європейської Конвенції про захист прав людини і основоположних свобод [2; 3].

На необхідності дотримання Україною вищезазначених вимог Європейської Конвенції неодноразово вказувалося представниками Європейського Союзу та США, особливо під час розгляду в Верховній Раді України чергових законопроєктів щодо запровадження кримінальної відповідальності за наклеп та образу [4].

Слід вказати, на цей час, права, які, встановивши кримінальну відповідальність, так прагне захистити законотворець, гарантовані статтею 28 (право на повагу до гідності) та статтею 32 (право на таємницю особистого та сімейного життя) Конституції України. Вказані права є особистими немайновими правами фізичної особи, відносяться до предмета регулювання саме цивільного права (глава 22 Цивільного кодексу України). Як зазначало Головне науково-експертне управління апарату Верховної Ради України у своєму висновку до законопроєкту В. С. Журавського, рекомендуючи відхилити його ще у першому читанні,його автор не обгрунтував та не навів доказів достатності підстав та принципів криміналізації наклепу [5]. Згідно 3 висновком управління «немайнові особисті (приватні) права осіб, якими $є$ честь, гідність, репутація, відносяться до предмету регулювання цивільного права». Крім того, прийняття закону могло призвести до порушення міжнародних зобов'язань України перед Радою Європи, саме на вимогу ПАРЕ закон про наклеп був виключений з кримінального кодексу [6;7].

Відповідно до ч.4 ст.32 Конституції України кожному гарантується судовий захист права спростовувати недостовірну інформацію про себе і членів своєї сім'ї та права вимагати вилучення будь-якої інформації, а також право на відшкодування матеріальної і моральної шкоди, завданої збиранням, зберіганням, використанням та поширенням такої недостовірної інформації.Для захисту честі та гідності фізична особа має право звернутися до суду з позовом (ч.3 ст.297 ЦК України). Аналогічна норма щодо судового захисту закріплена 
і у ч.2 ст.299 ЦК України. Прихильники впровадження відповідальності за наклеп вказують на недієвість цивільно-правового захисту, який до того ж не несе жодної превентивної функції [8]. На думку законотворців, свободу слова в Україні все частіше плутають зі вседозволеністю поширення відверто неперевірених, а то і зовсім помилкових фактів [8]. До того ж, кримінальна відповідальність за розповсюдження певного виду інформації не є чимось винятковим у чинному законодавстві, на що неодноразово зверталась увага вітчизняних науковців [9, с. 263].

Зокрема, ч. 2 ст. 301 КК України встановлюе кримінальну відповідальність за розповсюдження кіно- та відеопродукції, комп'ютерних програм порнографічного характеру; ч. 2 ст. 109 КК України за публічні заклики до насильницької зміни чи повалення конституційного ладу або до захоплення державної влади, а також розповсюдження матеріалів із закликами до вчинення таких дій; ст. 182 КК України за поширення конфіденційної інформації про особу; ст. 381 КК України за розголошення відомостей про заходи безпеки щодо особи, взятої під захист.

Не все так однозначно і з законодавством країн Європи та США. Незважаючи на численні звернення європейських політиків щодо обов'язків України із забезпечення свободи слова та діяльності журналістів, в абсолютній більшості демократичних країн світу залишаються кримінальноправові норми з відповідальності за дифамацію (наклеп або образу). Кримінальна відповідальність за наклеп передбачена в Австрії, Болгарії, Греції, Данії, Ісландії, Іспанії, Аатвї, Аитві, Німеччині, Норвегії, Польщі, Фінляндії, Франції, Хорватії, Чорногорії, Чехії, Швейцарії, Швеції [8; 10]. При цьому, в абсолютній більшості кримінальних кодексів європейських країн, незважаючи на період їх прийняття, містяться як загальні,так і спеціальні норми про відповідальність за наклеп та обра3у.

Загальні норми про відповідальність за образу та наклеп майже в усіх кодексах європейських країн мають окремі розді- ли або глави. Кримінальна відповідальність за вказані дії передбачається главою XXII КК Аитовської республіки «Злочини та кримінальні проступки проти честі та гідності особи» [11], третім розділом КК Швейцарії «Злочинні діяння проти честі та в області таємної і приватної сфери» [12], розділом XI КК Іспанії «Злочини проти гідності особи» [13], розділом чотирнадцятим КК ФРН «Образа» [14], главою 27 КК Данії «Злочини проти честі та певних особистих прав» [15]. Окремо слід сказати про законодавство Голландії [16], яке передбачає відповідальність у розділі XVI КК «Дифамація» лише за наклеп та пасквільну дифамацію та кримінальне законодавство Франції [17], яке не розглядає дифамацію у як злочин і встановлює відповідальність лише за непублічну дифамацію (ст. ст. 6211, 621-1). Зазначені діяння, за рішенням французького законодавця, відносяться лише до порушень 1-го класу. При цьому зазначається, що дійсність дифамаційних фактів може бути встановлена у відповідності із законодавчими положеннями, що відносяться до свободи преси.

Згідно 3 норвезьким законодавством про дифамацію є три варіанти реагування на поширення недостовірної інформації про особу, а саме: накладання штрафу відповідно до положень статей 246 і 247 Кримінального кодексу, видання наказу згідно зі статтею 253 Кримінального кодексу, що нівелює заяву 3 наклепом (mortifikasjon) і видання наказу відповідно до Закону про відшкодування збитків від 1969 р. про виплату компенсацій постраждалій стороні. Умови притягнення відповідача до відповідальності за наклеп викладені в розділі 23 Кримінального кодексу, стаття 247 якого передбачає:«Будьяка особа, яка словом або ділом поводиться у спосіб, який, імовірно, завдасть шкоди чесному імені або репутації іншої особи або призведе до ненависті, зневаги або втрати довіри до цієї особи, яка $є$ необхідною для іiі посади або ведення бізнесу, або є причетною до цього, нестиме відповідальність у вигляді штрафів або ув'язнення на період, що не перевищує один рік. Якщо наклеп здійснено в друкованій формі або у формі 


\section{Адміністративне право}

трансляції, або в інший спосіб за особливо обтяжувальних обставин, може бути передбачено ув'язнення на строк, що не перевищує два роки» [18, с. 196-197].

Передбачає кримінальну відповідальність за наклеп також більшість штатів CIIIA [8].

Спеціальні норми стосуються особливих категорій потерпілих та передбачають, у значній частині, відповідальність за образу органів державної або судової влади та ії представників. Зокрема, ст. 434-24 КК Франції, ст. 232 КК Аитовської республіки та ст. 504 КК Іспанії передбачають відповідальність за образу судової влади; КК Іспанії та КК ФРН за образу державної влади та держави взагалі, її символів (ст. ст. 496, 543 КК Іспанії, § 90, § 90а, § 90b КК ФРН, ст. 113-1 КК Голландії, § 129а КК Данії), релігійних почуттів (ст. 525 КК Іспанії, § 166 КК ФРН, ст. 147а КК Голландії), КК ФРН також передбачає спеціальну відповідальність за наклеп на політичного діяча (§ 188), публічну неправдиву підозру (§ 165), паплюження пам'яті померлого (§ 189). Вказані норми передбачають посилення відповідальності винних осіб, передбачаючи підвищений штраф або позбавлення волі на строк, термін якого, в окремих випадках, в два і більше разів перевищує покарання за загальною нормою про наклеп та образу (§ 188 КК ФРН) [19, c. 246].

Містять кримінальні заборони за наклеп також кримінальні кодекси більшості країн СНД, зокрема Азербайджану, Білорусі, Казахстану, Молдови, РФ, Таджикистану,Туркменії та Узбекистану. Більше того, значна кількість цих країн передбачає спеціальні норми про відповідальність за наклеп та образу представників влади, Президента країни, зокрема Білорусь, РФ, Таджикистан, Туркменія, Узбекистан [20, с. 472-475]. У Республіці Білорусь взагалі останнім часом суттєво розширено перелік злочинних діянь, зокрема за критику влади в засобах масової інформації, особливо в мережі Інтернет та соціальних мережах (Telegram, Facebook) тощо [21].

Дослідивши проблему відповідальності за наклеп у європейських країнах,
B. I. Павликівський робить висновок про те, що, незважаючи на суттєвий прогрес у сфері захисту свободи слова,кримінальне законодавство окремих країн передбачає відповідальність не тільки за умисний наклеп, але й за розповсюдження відомостей, які особа помилково вважає достовірними (КК Швейцарії, КК ФРН), а в окремих випадках навіть за розповсюдження достовірної інформації (КК ФРН) [19, с. 248].

Слід зазначити, що законодавство встановлює не тільки права, а й відповідні обов'язки журналіста. Зокрема, відповідно до закону України «Про друковані засоби масової інформації (пресу) в Україні» журналіст зобов'язаний подавати для публікації об'єктивну і достовірну інформацію (п. 2 ч. 3 ст. 26). Ті ж вимоги присутні у п. в та п. і ст. 59 законуУкраїни «Про телебачення та радіомовлення». Творчий працівник телерадіоорганізації зобов'язаний перевіряти достовірність одержаної ним інформації (п. б, г ч. 1 ст. 60, абзац 11 ч. 2). Наголошуючи на цьому, В. Підгородинський вважає обгрунтованим встановлення відповідальності журналістів за умисне розповсюдження завідомо неправдивої інформації, що в цілому стимулює останніх до добросовісного виконання свої роботи. Як зазначає науковець, авторитетні газети, журнали та їх працівники самі дбають про свою професійну репутацію і жодного звернення щодо захисту честі та гідності за їхніми публікаціями практично не спостерігається. Для таких видань на першому місці власна репутація, а вже далі - прагнення сподобатися читачеві [9, с. 266]. До аналогічних висновків прийшов Европейський суд з прав людини. Згідно з рішенням по справі «Тенсбергс Блад АС» і Гауком проти Норвегії» (Заява № 510/04)недоведені або завідомо неправдиві фактичні наклепницькі твердження не можуть бути захищені свободою вираження поглядів.

\section{Висновки}

Проведене дослідження 3 проблеми криміналізації наклепу та образи дає підстави стверджувати про те, що кримінальне законодавство зарубіжних країн, а також рішення Європейського суду з прав люди- 
ни допускають можливість кримінальної відповідальності за дифамацію. Одним 3 основних застережень у цьому випадку виступає стаття 10 Европейської конвенціїпро захист прав людини і основоположних свобод, яка встановлюе право кожного на свободу вираження поглядів. У той же час, умисне розповсюдження завідомо неправдивої інформації не захищене свободою вираження поглядів і може бути підставою переслідування порушників, у тому числі кримінально-правовими заходами.

Встановлення кримінальної відповідальності у такому випадку, враховуючи рівень розвитку демократичних інститутів і громадянського суспільства в Україні та країнах Европейського Союзу, повинне бути досліджене на предмет відповідності підставам та принципам криміналізації суспільно небезпечного діяння та наслідками реального застосування таких норм вітчизняною правоохоронною і судовою системами.

\section{література}

1. Судебная практика Европейского Суда по правам человека по статье 10 Европейской Конвенции: Т. 2 / Под редакцией Г. Ю. Араповой. Санкт-Петербург, 2004. 288c.

2. Конвенція про захист прав людини i основоположних свобод. URL: https:// zakon.rada.gov.ua/laws/show/995 004\#Text (дата звернення 5.11.2021).

3. Кримінальна відповідальність за наклеп - крок до обмеження свободи слова в Україні. URL:https://www.irf.ua/ kriminalna_vidpovidalnist_za_naklep_krok do_obmezhennya_svobodi_slova_v_ukraini/ (дата звернення 5.11.2021).

4. Генсек Ради Европи просить не душити свободу ЗМІ в Україні. Українська правда. 2012-09-22.URL:https:/www. pravda.com.ua/news/2012/09/22/6973270/ (дата звернення 5.11.2021).

5. П'ять років за наклеп: радянські репресії повертаються (Документ). Главком. 18 вересня 2012. URL:https:/glavcom.ua/ publications/1 18638-p\% E2\%80\%99jat-rokivza-naklep-radjanski-represiji-povertajutsjadokument.html(дата звернення 5.11.2021).
6. Проект Закону «Про внесення змін до Кримінального та Кримінального процесуального кодексів України щодо посилення відповідальності за посягання на честь, гідність та ділову репутацію людини» № 11013 від 19.07.2012 p. URL:https:// web.archive.org/web/20120926153933/ http://w 1.c1.rada.gov.ua/pls/zweb n/webpro c4 1?id=\&pf3511=44065 (дата звернення $5.11 .2021)$.

7. Ухвалення закону про наклеп - свідома провокація влади (Документ) Главком. 1 жовтня 2012. URL:https://glavcom.ua/ publications/1 18754-uhvalennja-zakonupro-naklep---svidoma-provokatsija-vladidokument.html(дата звернення 5.11.2021).

8. Пояснювальна записка до проєкту Закону України «Про внесення змін до Кримінального та Кримінального процесуального кодексів України щодо встановлення відповідальності за наклеп» URL: https://ips.ligazakon.net/ document/GH76I00A?an=2(дата звернення $5.11 .2021)$.

9. В. Підгородинський. Криміналізація наклепу і свобода слова в Україні. Право України. 2013. № 6. С. 262-267.

10. Закони та практика 3MI у одинадцяти демократіях світу (порівняльний аналiз) ARTICLE 19, Харківська правозахисна група. Харків: Фоліо, 2000. 200 с.

11. УК Аитовской республики. СанктПетербург: Издательство «Юридический центр Пресс», 2003. 470 с.

12. Уголовный кодекс Швейцарии. Москва: Издательство «Зерцало», 2000. $138 \mathrm{c}$.

13. Уголовный кодекс Испании. Москва: Издательство «Зерцало», 1998. 218 с.

14. Уголовный кодекс ФРГ. Москва: Издательство «Зерцало», 2000. 208 с.

15. Уголовный кодекс Дании.СанктПетербург: Издательство «Юридический центр Пресс», 2001. 230 с.

16. Уголовный кодекс Голландии. Санкт-Петербург: Издательство «Юридический центр Пресс», 2000. 253 с.

17. Уголовный кодекс Франции. СанктПетербург: Издательство «Юридический центр Пресс», 2002. 650 с. 


\section{Адміністративне право}

18. Справа «Тенсбергс Блад АС» i Гауком проти Норвегії». Рішення Європейського Суду з прав людини щодо доступу до публічної інформації. Рада Європи. Видавництво: «К.І.С.», 2017. 211 с.

19. Павликівський В.I. Кримінальна відповідальність за дифамацію (європейський досвід) // Право і суспільство. № 2. 2015. C. 243-249.

20. Павликівський В. І. Кримінальноправове забезпечення свободи слова та професійної діяльності журналістів в Україні. Харків: Панов, 2016. 488 с.

21. У Білорусі запровадили кримінальну відповідальність за підписку на опозиційні канали в Telegram. Радіо свобода. 13 жовтня 2021 p. URL: https://www.radiosvoboda. org/a/news-bilorus-vidpovidalnist-zapidpysku/31507275.html (дата звернення $5.11 .2021)$.

\section{SUMMARY}

The necessity and expediency of introduction into national legislation of criminal law norms on defamation and defamation and their impact on freedom of speech and journalism are studied. The author conducted a comparative legal analysis of the criminal laws of foreign countries on criminal liability for these actions. It is established that almost every European country, as well as a significant number of CIS countries has rules on criminal liability for defamation (in its various variations).

The arguments of both opponents and supporters of the introduction of a criminal law ban on defamation are investigated. It is concluded that it is possible to introduce liability for defamation and insult as an exceptional preventive measure to influence the violator in case of intentional dissemination of knowingly false information.

Key words: freedom of speech, right to information, defamation, slander, insult, criminal liability. 